\title{
Warm Antibody Autoimmune Hemolytic Anemia
}

National Cancer Institute

\section{Source}

National Cancer Institute. Warm Antibody Autoimmune Hemolytic Anemia. NCI

Thesaurus. Code C162611.

The most common form of autoimmune hemolytic anemia, in which the autoantibodies react with red blood cells at temperatures greater than or equal to 37 degrees Celsius. 